\title{
Wheat and Barley Straw for Production of Mushrooms
}

\author{
Sridevi Tallapragada ${ }^{1}$, Ajay Singh ${ }^{2}$, Anjum Varshney ${ }^{3}$ and Manjit Singh ${ }^{4}$ \\ ${ }^{1}$ Krishi Vigyan Kendra, Panchkula, India \\ ${ }^{2}$ Maharana Pratap Horticultural University, Karnal, India \\ ${ }^{3}$ Directorate of Wheat Development, Ghaziabad, India \\ ${ }^{4}$ ICAR-Directorate of Mushroom Research, Solan, India \\ *Corresponding author
}

\section{A B S T R A C T}

In nineteenth century, humans could produce food only for survival. In the last century, produced adequate food and food for convenience has been an important aspect in the fast growing and developing world where, people

\section{Keywords}

Wheat and barley straw, Mushrooms, Button mushroom

\section{Article Info}

Accepted:

14 June 2020

Available Online:

10 July 2020 have very little time to cook and were adapted to ready-to-eat food. In the recent years, functional foods have gained popularity within health and wellness circles. Functional foods are with ingredients that would offer health benefits along with good value with nutrition where in some are with supplements and add additional ingredients designed to improve health. Mushrooms are one such functional food, They have become attractive and functional food and as a source of drugs and due to its antioxidant, antitumor and antimicrobial properties it is a used vastly in nutraceuticals and pharmaceutical companies. Mushroom is also important in our diet due to their nutritional value, high protein and low fat contents.

\section{Introduction}

In nineteenth century, we could produce food only for survival. In the last century, we produced adequate food and food for convenience has been an important aspect in the fast growing and developing world where, people have very little time to cook and were adapted to ready-to-eat food. In the recent years, functional foods have gained popularity within health and wellness circles. Functional foods are with ingredients that would offer health benefits along with good value with nutrition where in some are with supplements and add additional ingredients designed to improve health. Mushrooms are one such functional food, they have become attractive and functional food and as a source of drugs and due to its antioxidant, antitumor and antimicrobial properties it is a used vastly in 
nutraceuticals and pharmaceutical companies. Mushroom is also important in our diet due to their nutritional value, high protein and low fat contents.

\section{Holistic recycling of straws by mushrooms}

India is an agrarian based economy. With the variety of agricultural crops grown today, we have achieved food security by producing over 280 million tonnes of food grain. However, our struggle to achieve nutritional security is still on. Another outcome of increased cereal production is the production of straws. Next revolution in agriculture will depend upon our ability to efficiently recycle these straws. In future the ever-increasing population, depleting agricultural land, changes in environment, water shortage and need for quality food products at competitive rates are going to be important issues. In order to meet these challenges and provide food and nutritional security to our people it is important to diversify. Mushrooms are one such component which not only use straw as a growth substrate for production of quality food but the material left after growing mushrooms know as mushroom compost that is high in organic matter and making it highly desirable for the use as soil amendment or as soil conditioner thus making a complete recycling of the straw (Fig. 1). Introduction of such component in the farming system will make the system holistic and more sustainable.

\section{Mushrooms for quality food, environment \& Health}

Producing mushrooms by using agri-residues not only address the issue of production of quality food and environmental issues (like pollution due to burning of straws), but can also address the health aspect as many mushroom are known to have medicinal value. Mushroom cultivation has high income generating potential and there is increased recognition of the nutritional value of mushrooms. Mushrooms are a health food. The consumption of mushrooms can make a valuable addition to the often unbalanced diets of people in our country. Mushrooms are a good source of vitamin B, C and D, including niacin, riboflavin, thiamine, and foliate, and various minerals such as potassium, phosphorus, calcium, magnesium, iron and copper. Mushrooms are an excellent source of high quality protein. Majority of population is deficient in Vitamin D due to the changed life style. Mushrooms are the only vegetable food that contains Vitamin D. It has been demonstrated that exposing mushroom to UV light for about 15 minutes increases the Vitamin D content by 100 times.

\section{Why grow mushrooms}

Mushrooms can be successfully grown without access to land, and can provide a regular income throughout the year. Small scale cultivation of some mushroom species as a seasonal activity does not require much investment. Mushrooms are grown on abundantly available raw materials - agro wastes. Ecologically too, cultivating mushrooms is having great relevance as after producing wealth from the waste, the remaining substrate gets recycled as manure in fields thereby improving soil health, reducing use of chemicals and thus promoting organic farming. Substrates like wheat straw, rice straw, sugarcane bagasse, saw dust, corn cobs, pearl millet, sorghum, mustard stalks, soybean waste, cotton waste, etc. along with other materials like rice or wheat bran, molasses, various cakes, chicken manure, etc. are used for cultivation of button, oyster, milky and paddy straw mushroom and can also be used for cultivation of shiitake, woodear mushroom, winter mushroom and many others. Each of these mushrooms has a specific requirement in terms of temperatures 
ranging from 10 to 40 degree Celsius (Fig. 2).

\section{Cereal straws produced in India}

No exact data on straw production is available. However, we can estimate it from the crop yields. The estimated straw production based on average crop production of last five years (2014 to 2018) is given in Table 1 . We can see that maximum straw is produced during wheat and rice cultivation. The contribution of barley is relatively very low. These straws are used as animal feed and also for cultivation of mushrooms. The quantity of wheat straw used for mushroom production in our country is, however, miniscule $(0.13 \%)$.

\section{China uses about $4 \%$ of crop residues for mushrooms}

China, being largest producer of mushrooms was using only $2 \%$ of crop residues for its cultivation in 2008-09 (Fig. 3). There has been rapid increase in mushroom production in last decade in China and production has almost doubled since then. It can be estimated that at present approximately $4 \%$ of the residues get utilized for mushroom production.

\section{How much wheat straw is needed to equal world mushroom production}

Residues from wheat and barley in our country are about 150 million tonne. World over these straws are used for production of button mushroom. The world button mushroom production is about six million tons (Table 2 and India's share in button production is about $1.5 \%$ only.

In India, we normally get 2.5 ton compost per ton of wheat straw and get 20\% Biological Efficiency (i.e. $20 \mathrm{~kg}$ fresh mushroom per 100 $\mathrm{kg}$ compost). At these production levels, about $8 \%$ of straw will be enough to produce 6 million tonne, that is, amount equal to the current button mushroom production in the world (Table 3). Our production levels of button mushroom are below international standards. In Netherlands and other developed countries the $\mathrm{BE}$ is about $32 \%$ or more. In that case, we may need less than $5 \%$ of the straws to equal global button mushroom production.

Being an indoor crop, the commodity provides immense opportunities for empowerment of rural and urban women through cultivation and also the production of value-added products.

\section{Mushrooms cultivated in India}

At present the four commonly cultivated edible mushrooms in the country are:

Button mushroom (Agaricus bisporus)

Oyster mushroom (Pleurotus spp.)

Milky mushroom (Calocybe indica)

Paddy straw mushroom (Volvariella volvacea)

Button mushroom is mainly cultivated in North India both under controlled and natural conditions. There are units in Maharashtra, and other parts of the country. Other three mushrooms in India are cultivated under natural conditions. Of these oyster mushroom is cultivated in all parts of the country but is more popular in NE region. Milky mushroom is mainly cultivated in South India and paddy straw mushroom is cultivated mainly in coastal regions of Odisha (Fig. 2). Cultivation of mushrooms started in India in 70's and there has been rapid growth in last two decades. At present the total mushroom production in our country is about 130 million $\mathrm{kg}$ of which the major contribution is by 
button mushroom (Fig 4) and major mushroom producing states are Maharashtra, Haryana. Punjab and Gujarat(Fig. 5).

Commercial production of edible mushrooms bioconverts the residues into nutritious food (mushrooms). Indoor cultivation of mushrooms utilizes the vertical space and is regarded as the highest protein producer per unit area and time-almost 100 times more than the conventional agriculture and animal husbandry. This hi-tech horticulture venture has a promising scope to meet the food shortages without undue pressure on land. In addition, it is a unique venture for employment generation.

\section{Mushroom consumption}

With increasing population, urbanization and changing food habits, demand for quality foods like mushrooms is going to increase in coming decades. As already mentioned, mushrooms are a rich protein source having essential amino-acids and high digestibility. Mushrooms are also good for heart as they have got low fat, no cholesterol, have more of unsaturated fatty acids and some of the mushrooms have compounds that are known to lower the cholesterol in the blood. Moreover, mushrooms have low-sodium and high potassium content making it a suitable food for persons suffering from high blood pressure.

Table.1 Estimated Cereal straw production in India (based on average of crop production data of 2014 to 2018)

\begin{tabular}{|c|c|c|c|}
\hline Crop & $\begin{array}{l}\text { Av yield (million tonne) } \\
\text { (2013-14 to 2017-18 }\end{array}$ & $\begin{array}{c}\text { Harvest } \\
\text { index* }\end{array}$ & $\begin{array}{c}\text { Residues } \\
\text { (million tonne) }\end{array}$ \\
\hline Wheat & 95 & $1: 1.5$ & 142 \\
\hline Rice & 108 & $1: 1.3$ & 140 \\
\hline Maize & 25 & $1: 4$ & 100 \\
\hline Pearl millet & 9 & $1: 4$ & 36 \\
\hline Sorghum & 5 & $1: 3$ & 15 \\
\hline Barley** & 1 & $1: 1.5$ & 2 \\
\hline Others & & & 6 \\
\hline TOTAL & & & 441 \\
\hline
\end{tabular}

based on Agricultural Statistics at a Glance (DAC\& FW), 2018

* based on Policy Paper 49 on Agriculture Waste Management, Dec 2010, NAAS, New Delhi

** based on https://aps.dac.gov.in/APY/Public_Report1.aspx

Table.2 Button production in the world (2017-18)

\begin{tabular}{|l|l|}
\hline Country & Million Ton \\
\hline China & 3.35 \\
\hline Europe & 1.29 \\
\hline USA & $\mathbf{0 . 4 0}$ \\
\hline Canada & $\mathbf{0 . 1 2}$ \\
\hline India & $\mathbf{0 . 1 0}$ \\
\hline Australia & $\mathbf{0 . 0 7}$ \\
\hline Others & $\mathbf{0 . 6 0}$ \\
\hline TOTAL & $\mathbf{5 . 9 4}$ \\
\hline
\end{tabular}


Table.3 Button production at different levels of straw utilization

\begin{tabular}{|l|c|c|}
\hline $\begin{array}{l}\text { Agro residues } \\
\text { Million tonnes }\end{array}$ & $\begin{array}{c}\text { Percent } \\
\text { utilization }\end{array}$ & $\begin{array}{c}\text { Mushroom } \\
\text { production } \\
\text { (India level)* }\end{array}$ \\
\hline $\mathbf{1 5 0}$ & $1 \%$ & $\mathbf{0 . 7 5}$ \\
\hline $\mathbf{1 5 0}$ & $2 \%$ & $\mathbf{1 . 5}$ \\
\hline $\mathbf{1 5 0}$ & $4 \%$ & $\mathbf{3}$ \\
\hline $\mathbf{1 5 0}$ & $6 \%$ & $\mathbf{4 . 5}$ \\
\hline $\mathbf{1 5 0}$ & $8 \%$ & $\mathbf{6}$ \\
\hline $\mathbf{1 5 0}$ & $\mathbf{1 0 \%}$ & $\mathbf{7 . 5}$ \\
\hline
\end{tabular}

Fig.1 Complete recycling of agro-wastes by production of mushrooms

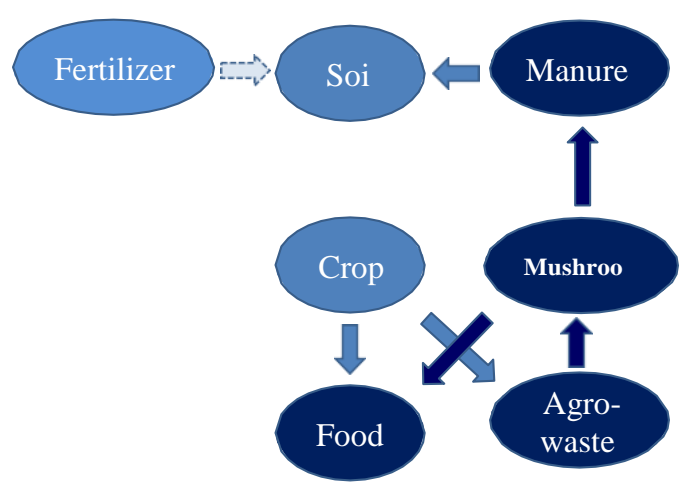

Figure.2 Major mushrooms under cultivation in India and dominant areas of their cultivation

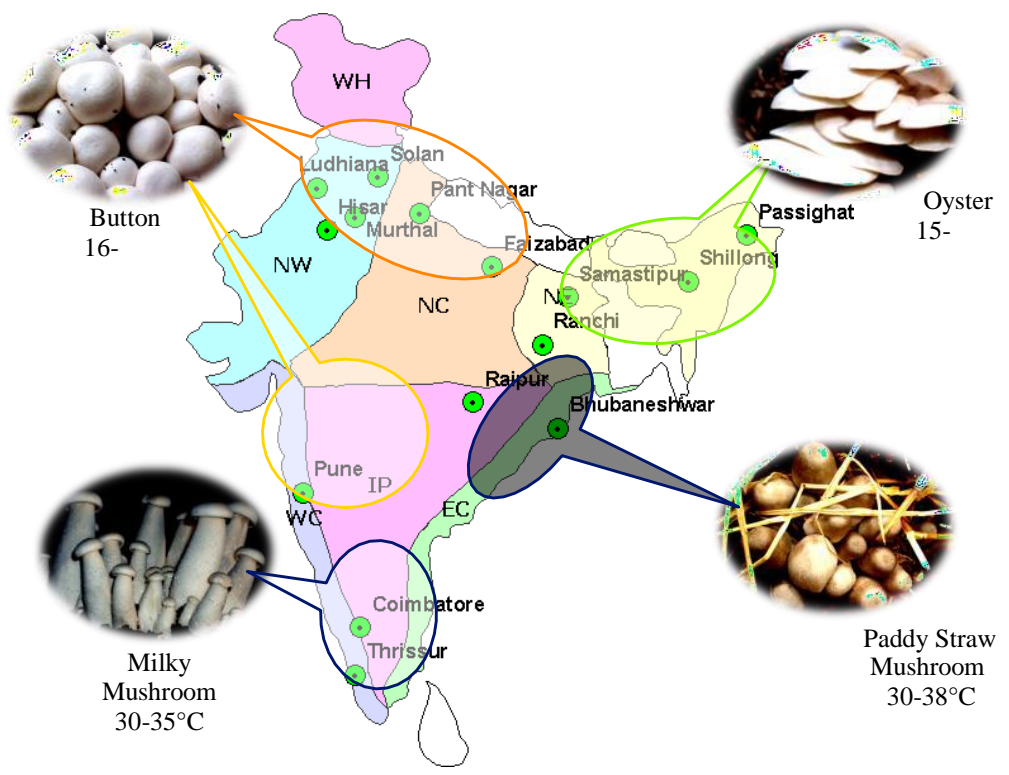


Figure.3 Crop residue utilisation in China in 2008-09

(Wang et al., 2013, Renewable and Sustainable Energy Reviews 27: 864-875)

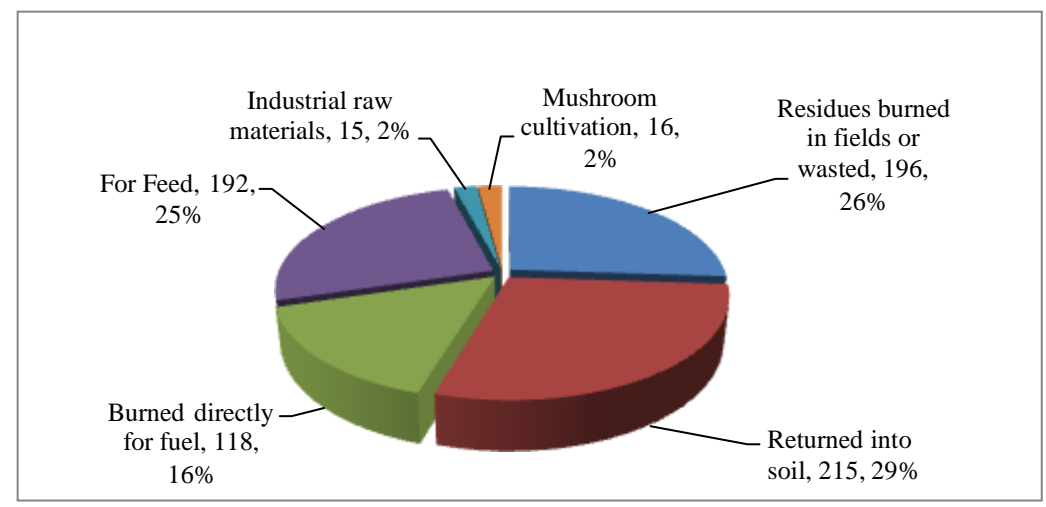

Of 130 million $\mathrm{kg}$ mushroom production in India in 2016, button mushroom accounted for 95, oyster 22, Volvariella 10 and Milky mushroom about 3 million $\mathrm{kg}$

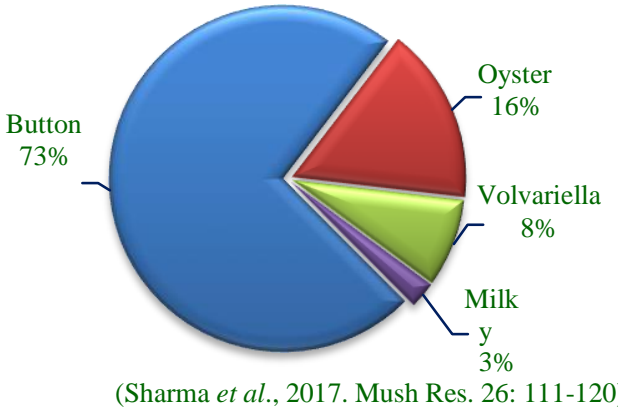

Figure 4. Total mushroom production in the country in 2016

The mushrooms are also considered delight of diabetics as it is a low calorie food with no starch and has also number of anti-oxidants. These are also rich in fibres and hence good for digestive system. These attributes put the mushroom in the category of functional foods. An awareness generation about their nutritional and medicinal values is important to popularize mushroom among the masses and break consumer resistance observed in many pockets due to misinformation about its edibility and nature.

In India mushroom consumption is about $80 \mathrm{~g}$ per capita. In China per person per year consumption of mushroom is about $22 \mathrm{~kg}$.

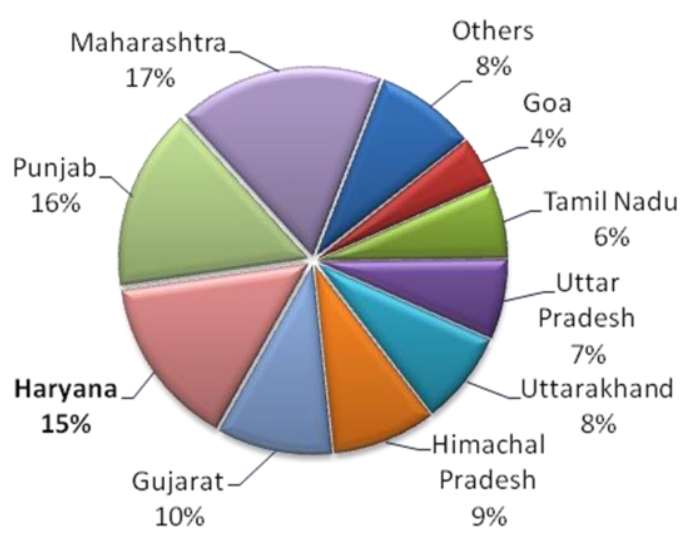

Figure 5. Contribution of different states in mushroom production

Global average consumption is approaching 6 $\mathrm{kg} /$ person/year. Thus there is ample scope of promoting mushrooms in our country. Even if we increase our production 10 times, still our consumption will be less than one $\mathrm{kg}$ meaning thereby that India has tremendous market. The production becomes meaningful when there is increase in consumption/demand. To enhance local consumption there is need for popularising the cooking methods and health benefits of mushrooms.

In conclusion, Indian agriculture will continue to be a main strength of Indian economy. Considering the natural resources available in the form of agro-wastes, a predominant rural 
based economy, prevalence of educated youth looking for suitable vocations, there is ample scope for growth of mushroom industry in the country. This is one of the good options to earn instead to burn the straws available in plenty.

\section{References}

Chadha, K.L. and Sharma, S.R. 1995. Advances in Horticulture. Volume 13, Mushroom. Malhotra Publishing House, New Delhi, 649 p.

Chang, S.T. and Miles, P.G. 2004. Mushrooms: Cultivation, Nutritional Value, Medicinal Effect, and Environmental Impact.

CRC Press, Boca Raton, $451 \mathrm{p}$.

Griensven, L.J.L.D. 1988. The Cultivation of
Mushrooms. Darlington Mushroom Laboratories Ltd., England, 515 p.

Kaul, T.N. and Dhar, B.L. 2007. Biology and Cultivation of Edible Mushrooms. Westville Publishing House, New Delhi, 225 p. Stamets, P. 2002. Growing gourmet and medicinal mushrooms, Ten speed press, California.

Singh Manjit, B. Vijay, S. Kamal and GC Wakchaure (eds). 2011. Mushrooms Cultivation, Marketing and consumption.

Directorate of Mushroom Research, Solan (HP), 266p.

Vedder, P.J.C. 1978. Modern Mushroom Growing. Educaboek, Netherlands, 420 p.

\section{How to cite this article:}

Sridevi Tallapragada, Ajay Singh, Anjum Varshney and Manjit Singh 2020. Wheat and Barley Straw for Production of Mushrooms. Int.J.Curr.Microbiol.App.Sci. 9(07): 1498-1504. doi: https://doi.org/10.20546/ijcmas.2020.907.172 